\title{
The influence of low-level laser therapy on biomodulation of collagen and elastic fibers
}

\section{A influência da terapia a laser de baixa densidade de energia na biomodulação das fibras colágenas e elásticas}

\author{
Livia Souza Pugliese* \\ Alena Peixoto Medrado* \\ Sílvia Regina de Almeida Reis** \\ Zilton de Araújo Andrade***
}

\begin{abstract}
The study of low-level laser therapy upon extracellular matrix elements is important to understand the wound healing process under this agent. However, little is known about the interference of laser light in relation to collagen and elastic fibers. Cutaneous wounds were performed on the back of 72 Wistar rats and a Ga-Al-As low-level laser was punctually applied with different energy densities. The animals were killed after 24, 48, 72 hours and 5,7 and 14 days. Tissues were stained with hematoxilin-eosin, sirius red fast green and orcein and then analyzed. It was observed that the treated group exhibited larger reduction of edema and inflammatory infiltrate. The treated animals presented a larger expression of collagen and elastic fibers, although without statistical significance $(p>0.05)$. Treatment with a dosage of $4 \mathrm{~J} / \mathrm{cm}^{2}$ exhibited more expressive results than that with $8 \mathrm{~J} / \mathrm{cm}^{2}$. In this study, the authors concluded that low-level laser therapy contributed to a larger expression of collagen and elastic fibers during the early phases of the wound healing process.
\end{abstract}

DESCRIPTORS: Lasers; Laser therapy, low-level; Wound healing; Collagen.

RESUMO: O estudo da terapia a laser de baixa densidade de energia sobre os diversos constituintes da matriz extracelular é crucial para o entendimento do processo cicatricial sob esse agente. Todavia, pouco se sabe sobre a interferência do laser em relação às fibras colágenas e elásticas. Realizaram-se ferimentos cutâneos padronizados no dorso de setenta e dois ratos Wistar e, em seguida, aplicação pontual do raio laser de baixa potência do tipo Arseneto de Gálio-Alumínio (Ga-Al-As) com diferentes densidades de energia. Os animais foram sacrificados com 24, 48 e 72 horas e aos 5,7 e 14 dias. Procedeu-se à análise das secções teciduais coradas por hematoxilina-eosina, sírius vermelho e orceína. Observou-se, que nos grupos submetidos à terapia a laser, houve maior redução do edema e infiltrado inflamatório. Os animais tratados apresentaram uma maior expressão de fibras colágenas e elásticas, embora sem significância estatística $(p>0,05)$. No tratamento com a fluência de $4 \mathrm{~J} / \mathrm{cm}^{2}$ observaram-se melhores resultados do que naquele em que foi utilizada a fluência de $8 \mathrm{~J} / \mathrm{cm}^{2}$. Neste estudo, pôde-se concluir que o laser contribuiu para uma maior expressão de fibras colágenas e elásticas durante o processo cicatricial.

DESCRITORES: Lasers; Terapia a laser de baixa intensidade; Cicatrização de feridas; Colágeno.

\section{INTRODUCTION}

Repair is a dynamic state, comprising different processes, among which, inflammation, cellular proliferation and synthesis of the elements that constitute the extracellular matrix, such as collagen, elastic and reticular fibers ${ }^{15}$. The synthesis of collagen is processed as soon as the intersticial lesion begins, and is extended until the final healing phases, while the remodeling of the tissue occurs $^{13}$. In respect to the elastic fibers, it is known that its polypeptide chains are relatively free and unstructured, covalently crossed to form an elastic net that allows the tissues to extend without damage. The long collagen fibrils are interlaced with the elastic fibers in order to limit the expansion and avoid the laceration of the tissue ${ }^{1}$.

Nowadays, great emphasis has been directed at the application of laser irradiation of low energy density with the objective of accentuating the cellular biochemical reactions, and, this way, contributing to a significantly more efficient resolution of the wound. The sphere of action of the laser is very broad and there has been investigations

\footnotetext{
*Assistant Professors, Department of Basic Science, School of Dentistry, Foundation for the Development of Science, Salvador.

${ }^{* *}$ Associate Professor, Diagnosis and Therapeutics Department, Federal University of Bahia.

***Head of the Experimental Pathology Laboratory, Gonçalo Moniz Research Center, FIOCRUZ.
} 
Pugliese LS, Medrado AP, Reis SRA, Andrade ZA. The influence of low-level laser therapy on biomodulation of collagen and elastic fibers. Pesqui Odontol Bras 2003;17(4):307-13.

about its contribution to the repair process, particularly in respect to its influence on the modulation of certain cellular types that comprise the micro-environment of healing. Gomez-Villamandos et $a .^{4}{ }^{4}$ evidenced faster healing of wounds after laser therapy, with an increase in mitotic activity, fibroblast number, and the synthesis of collagen and neovascularization. Other authors ${ }^{18}$ observed that the production of FGF by the fibroblasts in culture medium increased considerably after irradiation with low level laser. Besides that, Bisht et $a l^{2}$ observed development of granulation tissue and fast re-epithelization on the wounds of rats treated with HeNe laser.

In view of the shortage of scientific studies aiming to characterize possible interferences of the low-power laser regarding the synthesis and maturation of the fiber components of the connective matrix, like the collagen and elastic fibers, the present study sought to verify in which way the laser therapy can act as a biostimulator resource on the cells which synthesize these fiber elements.

\section{MATERIALS AND METHODS Animals}

Seventy-two healthy male and female Wistar rats weighing 150-250 g were maintained in individual cages with free access to water and a pellet balanced commercial diet for rats. They were randomly divided into three groups of 24 animals each.

\section{Surgical procedure}

A single wound was inflicted on the dorsal skin of each animal. Under aseptic conditions and light anesthesia with ketamine-xylazine (Dopalen, SP, Brazil) a controlled, $8 \mathrm{~mm}$-diameter round skin wound was produced at the right dorsal region by means of a punch-skin biopsy device (Steefel, USA).

\section{Experimental groups}

- Group 1: Non-treated controls.

- Group 2: The animals were treated with a gallium-aluminum-arsenide diode laser (VR-KC-610 - Dentoflex, SP, Brazil), receiving $4 \mathrm{~J} / \mathrm{cm}^{2}$ of energy density upon the wound.

- Group 3: Likewise treated, but with a $8 \mathrm{~J} / \mathrm{cm}^{2}$ dose of energy density.

\section{Laser treatment}

A laser device was used containing a continuous-wave Ga-Al-As light emitting diode at $670 \mathrm{~nm}$ and with an output of $9 \mathrm{~mW}$ (Dentoflex-Brazil). Power output was calibrated by a power meter. In order to determine the time of cutaneous applications, the spot size was measured, and the quantity of energy density and power output were determined according to the Tuner, Hode equation ${ }^{16,17}$. The laser probe was applied punctually, in contact with the wound. Only a single session of treatment, immediately following surgery, was applied.

\section{Morphological studies}

On days $1,2,3,5,7$ and 14 following surgery and laser treatment, the wounds were grossly inspected in order to register any possible disturbance on wound healing and the animals were killed with ether under a hood.

\section{Histology}

Fragments of the skin, including the margin of the wound and subcutaneous tissue were fixed in 10\% phosphate buffered formalin (Qeel Ltda., SP, Brazil) and embedded in paraffin (Nuclear, CAQ, $\mathrm{SP}$, Brazil). Five $\mu \mathrm{m}$-thick sections were routinely stained with hematoxylin-eosin (Merck, Darmstadt, Germany), sirius red for collagen (Aldrich, Milwaukee, USA), and orcein for elastic fibers (Vetec Química Ltda., Rio de Janeiro, Brazil).

\section{Semi-quantitative analysis}

Changes of collagen and elastic fibers were semi-quantitatively evaluated in coded slides and registered as absent $(0)$, mild $(+)$, moderate $(++)$ and marked $(+++)$.

\section{Statistical analysis}

The differences between the control group and the experimental groups were analyzed by using the nonparametric Kruskal-Wallis one-way ANOVA-test for the histological data. Significance was accepted at $\mathrm{p}<0.05$.

\section{RESULTS}

During the post-surgery period, the animals remained healthy, with normal healing on the operated site, without clinical evidence of infection. In the group of dead animals within 24 hours, an intense polymorphonuclear inflammatory infiltrate and edema on the connective tissue was observed. The mononuclear cells, like the lymphocytes and plasma cells, were sparsely distributed in the wounded area. On the surface of the wound there were necrotic cells exhibiting picnotic nucleus and 
Pugliese LS, Medrado AP, Reis SRA, Andrade ZA. The influence of low-level laser therapy on biomodulation of collagen and elastic fibers. Pesqui Odontol Bras 2003;17(4):307-13.

karyorrhexis. The fibrin was concentrated on the surface of the wound, appearing strongly eosinophilic. In the animals from the groups submitted to the laser therapy it was observed that the inflammatory alterations were more discreet. In this period, the presence of collagen fibers was found in the wounded area which were in a disorganized arrangement, placed as small fibrils randomly distributed on the skin. The presence of elastic fibers was even more discreet, so that the short fibers were visualized dispersed in the connective matrix. Statistically significant differences were not observed between the groups studied.

Analysis of the animal group that was killed 48 hours after surgery demonstrated that all continued to show a histological scenario of acute inflammation, with expressive representation of polymorphonuclear leukocytes and edema. In the groups treated with laser, the inflammatory infiltrate was more discreet, and although the predominant cellular element was still the neutrophil, the expression of mononuclear cells could already be seen. The semi-quantitative study of the collagen synthesized by the cells present in the extracellular matrix revealed that there were no significant differences between the groups and only sparse collagen fibers were found present in the wounded

TABLE 1 - Distribution of collagen fibers in the control and laser treated groups at 24, 48 and 72 hours and 5, 7 and 14 days.

\begin{tabular}{|c|c|c|c|}
\hline $\begin{array}{l}\text { Time of } \\
\text { sacrifice }\end{array}$ & Group & Mean \pm SD & $\mathrm{p}^{*}$ \\
\hline 24 hours & $\begin{array}{l}\text { Control } \\
4 \mathrm{~J} / \mathrm{cm}^{2} \text { laser } \\
8 \mathrm{~J} / \mathrm{cm}^{2} \text { laser }\end{array}$ & $\begin{array}{l}1.00 \pm 0.0 \\
1.00 \pm 0.0 \\
1.00 \pm 0.0\end{array}$ & \\
\hline 48 hours & $\begin{array}{l}\text { Control } \\
4 \mathrm{~J} / \mathrm{cm}^{2} \text { laser } \\
8 \mathrm{~J} / \mathrm{cm}^{2} \text { laser }\end{array}$ & $\begin{array}{l}1.25 \pm 0.5 \\
1.50 \pm 0.5 \\
1.25 \pm 0.5\end{array}$ & 0.74 \\
\hline 72 hours & $\begin{array}{l}\text { Control } \\
4 \mathrm{~J} / \mathrm{cm}^{2} \text { laser } \\
8 \mathrm{~J} / \mathrm{cm}^{2} \text { laser }\end{array}$ & $\begin{array}{l}1.50 \pm 0.5 \\
1.75 \pm 0.5 \\
1.50 \pm 0.5\end{array}$ & 0.76 \\
\hline 5 days & $\begin{array}{l}\text { Control } \\
4 \mathrm{~J} / \mathrm{cm}^{2} \text { laser } \\
8 \mathrm{~J} / \mathrm{cm}^{2} \text { laser }\end{array}$ & $\begin{array}{l}1.50 \pm 0.5 \\
2.00 \pm 0.5 \\
2.00 \pm 0.0 \\
\end{array}$ & 0.10 \\
\hline 7 days & $\begin{array}{l}\text { Control } \\
4 \mathrm{~J} / \mathrm{cm}^{2} \text { laser } \\
8 \mathrm{~J} / \mathrm{cm}^{2} \text { laser }\end{array}$ & $\begin{array}{l}2.25 \pm 0.5 \\
2.75 \pm 0.5 \\
2.25 \pm 0.9\end{array}$ & 0.51 \\
\hline 14 days & $\begin{array}{l}\text { Control } \\
4 \mathrm{~J} / \mathrm{cm}^{2} \text { laser } \\
8 \mathrm{~J} / \mathrm{cm}^{2} \text { laser }\end{array}$ & $\begin{array}{l}3.00 \pm 0.0 \\
3.00 \pm 0.0 \\
3.00 \pm 0.0\end{array}$ & \\
\hline
\end{tabular}

*The mean difference is significant at the 0.05 level. area (Table 1). As in the normal dermis the concentration of collagen fibers was extremely high, its study served as reference for the comparative analysis with the pathological area.

Regarding the elastic fibers stained by orcein, it was observed that around the wound, represented by areas of normal skin, these structures were found dispersed in the stroma of connective tissue of the dermis, as well as being situated right below it, a little above the subjacent muscular tissue. Those present in the arterioles' elastic layers were well stained by orcein and allowed an analysis of the vascularization phenomenon in the wound area. In the groups of 24, 48 and 72 hours, few elastic fibers were visualized, independently of the groups studied (Figures 1 and 2). When present, they were found sparsely distributed in the matrix, in the form of small fibrils. There were no statistically significant differences between the groups studied (Table 2).

In the group of animals sacrificed in 72 hours, the appearance of new blood vessels and the migration of epithelial cells along the wound from the side borders of the lesion were observed. In the control animals there was moderate inflammatory infiltrate, especially in the more profound layers of the hypodermis.

TABLE 2 - Distribution of elastic fibers in the control and laser treated groups at 24, 48 and 72 hours and 5, 7 and 14 days.

\begin{tabular}{|c|c|c|c|}
\hline $\begin{array}{l}\text { Time of } \\
\text { sacrifice }\end{array}$ & Group & Mean \pm SD & $\mathrm{p}^{*}$ \\
\hline 24 hours & $\begin{array}{l}\text { Control } \\
4 \mathrm{~J} / \mathrm{cm}^{2} \text { laser } \\
8 \mathrm{~J} / \mathrm{cm}^{2} \text { laser }\end{array}$ & $\begin{array}{l}0.50 \pm 0.5 \\
1.00 \pm 0.0 \\
0.75 \pm 0.5\end{array}$ & 0.32 \\
\hline 48 hours & $\begin{array}{l}\text { Control } \\
4 \mathrm{~J} / \mathrm{cm}^{2} \text { laser } \\
8 \mathrm{~J} / \mathrm{cm}^{2} \text { laser }\end{array}$ & $\begin{array}{l}1.00 \pm 0.0 \\
1.00 \pm 0.0 \\
1.00 \pm 0.0\end{array}$ & \\
\hline 72 hours & $\begin{array}{l}\text { Control } \\
4 \mathrm{~J} / \mathrm{cm}^{2} \text { laser } \\
8 \mathrm{~J} / \mathrm{cm}^{2} \text { laser }\end{array}$ & $\begin{array}{l}1.00 \pm 0.0 \\
1.25 \pm 0.5 \\
0.75 \pm 0.5\end{array}$ & 0.27 \\
\hline 5 days & $\begin{array}{l}\text { Control } \\
4 \mathrm{~J} / \mathrm{cm}^{2} \text { laser } \\
8 \mathrm{~J} / \mathrm{cm}^{2} \text { laser }\end{array}$ & $\begin{array}{l}1.00 \pm 0.0 \\
1.50 \pm 0.5 \\
1.25 \pm 0.5 \\
\end{array}$ & 0.32 \\
\hline 7 days & $\begin{array}{l}\text { Control } \\
4 \mathrm{~J} / \mathrm{cm}^{2} \text { laser } \\
8 \mathrm{~J} / \mathrm{cm}^{2} \text { laser }\end{array}$ & $\begin{array}{l}1.00 \pm 0.0 \\
1.50 \pm 0.5 \\
1.25 \pm 0.5\end{array}$ & 0.32 \\
\hline 14 days & $\begin{array}{l}\text { Control } \\
4 \mathrm{~J} / \mathrm{cm}^{2} \text { laser } \\
8 \mathrm{~J} / \mathrm{cm}^{2} \text { laser }\end{array}$ & $\begin{array}{l}1.00 \pm 0.0 \\
1.25 \pm 0.5 \\
1.25 \pm 0.5\end{array}$ & 0.62 \\
\hline
\end{tabular}

*The mean difference is significant at the 0.05 level. 
Pugliese LS, Medrado AP, Reis SRA, Andrade ZA. The influence of low-level laser therapy on biomodulation of collagen and elastic fibers. Pesqui Odontol Bras 2003;17(4):307-13.

The animals which received an energy density of $4 \mathrm{~J} / \mathrm{cm}^{2}$ showed a histological scenario more favorable than that of the group treated with $8 \mathrm{~J} / \mathrm{cm}^{2}$. In the former, the re-epithelization present below the crust showed a higher number of newly formed epithelial layers. The angiogenesis revealed a considerable number of new capillaries being formed, superior to those of the control group. The inflammatory infiltrate was discreet. The alterations of the animals that received $8 \mathrm{~J} / \mathrm{cm}^{2}$ were very similar to those of the control group, including the presence of cellular infiltrate and smaller re-epithelization.

The histological cuts showed a moderate expression of collagen fibers, and those found showed a more organized pattern. It was verified that in the groups submitted to the laser therapy, the intensity of the stain was more evidenced, especially in the group that received $4 \mathrm{~J} / \mathrm{cm}^{2}$, although these differences were not statistically significant (Table 1).

From the $5^{\text {th }}$ day, the existence of a typical granulation tissue was observed in every studied group, characterized by the presence of blood vessels being formed and intense cellular proliferation. In the control group, the inflammatory infiltrate persisted, placed in focal areas of the dermis.
The histological analysis was enriched by a higher expression of collagen fibers (Figure 3). The groups treated with laser exhibited a more evident organization pattern, with more associated fibers. The sirius red stained in a more intense manner, revealing more centralized bundles of collagen fibers, and not only fibers sparsely distributed (Figure 4). The control group showed a similar aspect to that of the 72-hour group previously described. The expression of the collagen was relatively discreet. No statistical significance was detected between the groups.

In relation to the study of elastic fibers, it was possible to observe a greater distribution of individual fibers and expression of the fibers around newly formed small blood vessels, in all groups (Figure 5). In the bordering areas of the wound, it appeared to have a continuous strip of organized elastic fibers.

The observation of histologic sections on the $7^{\text {th }}$ day after surgery demonstrated that, in the control group, the phenomenon of re-epithelization was more accelerated in comparison to that of the groups treated with laser. In the control group one could observe the almost complete re-epithelization of the wound. The granulation tissue was present in all groups studied.
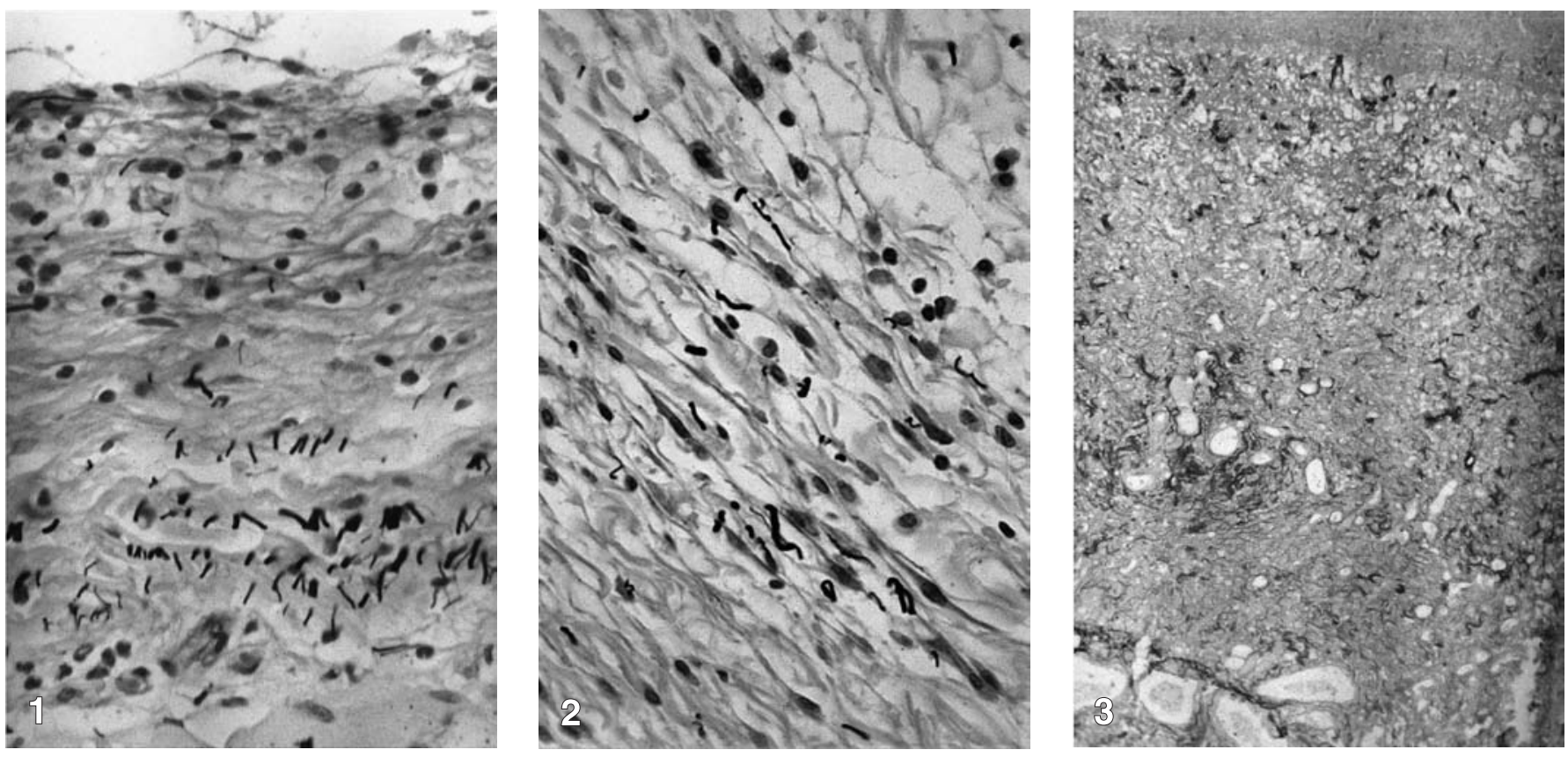

FIGURE 1 - Distribution of elastic fibers within the wound of a $8 \mathrm{~J} / \mathrm{cm}^{2}$ treated animal; seventy-two hours (Weigert's orcein, $400 \mathrm{X}$ ). FIGURE 2 - Distribution of elastic fibers within the wound of a $4 \mathrm{~J} / \mathrm{cm}^{2}$ treated animal; seventy-two hours (Weigert's orcein, $400 \mathrm{X}$ ). FIGURE 3 - Collagen fibers within extracellular matrix of a control animal; five days (Sirius red, $100 \mathrm{X}$ ). 
Pugliese LS, Medrado AP, Reis SRA, Andrade ZA. The influence of low-level laser therapy on biomodulation of collagen and elastic fibers. Pesqui Odontol Bras 2003;17(4):307-13.

Once more, the $4 \mathrm{~J} / \mathrm{cm}^{2}$ laser group revealed lighter histopathologic findings in relation to those of the other laser group, not showing evidence of inflammatory cells, so that, in the $8 \mathrm{~J} / \mathrm{cm}^{2}$ laser group there was still discreet inflammatory infiltrate, similar to that of the control group. The histological pattern of the $7^{\text {th }}$ day group was already similar to that observed in the normal dermis, regarding the collagen fibers (Figures 6 and 7).

Accordingly, the red stain of the collagen fibers was more intense, and they were arranged in a more organized manner in the groups treated with laser, although no statistically significant differences were found (Figures 8 and 9). The expression of the elastic fibers during the $7^{\text {th }}$ and $14^{\text {th }}$ day was very similar. They were present in the neighborhood of the healing fibrous tissue and their visualization in the scar area was minimal. Additionally, a restoration seemed to have occurred of the elastic fiber layer placed below the dermis, since the repair was performed gradually.

The analysis of the healing process in this study was performed until the $14^{\text {th }}$ day after surgery intervention. At this time, the differences between the groups were not as significant as in the previous periods. All the animals exhibited new com- plete epithelial formation and fibrous healing tissue, devoid of cutaneous attachments.

\section{DISCUSSION}

Although the clinical efficacy of the low-power laser has been proved through controlled studies $^{5,11}$, little is known about the histological alterations that can occur due to its use, particularly regarding modulation of the extracellular matrix elements. The interaction of monochromatic light with the cellular elements present in the connective tissue has been the object of study of some investigators ${ }^{9,12}$. However, there are few references regarding the action of laser therapy on the synthesis of the various types of fibers within the extracellular matrix.

Skinner et $a .^{14}$ used a pulsatile Ga-As laser applying different energy densities in cultures of fibroblasts of human embryos, and observed that there was a significant increase in the levels of collagen in the irradiated cells, through a radioactive proline test. Additionally, still within the sphere of biochemical studies, other authors demonstrated an increase in DNA and ATP synthesis in vitro ${ }^{7,10}$. The data of the present experimental study strongly suggest that the therapeutic laser modulates the expression of collagen and elastic fibers in vivo, although no statistically significant differ-
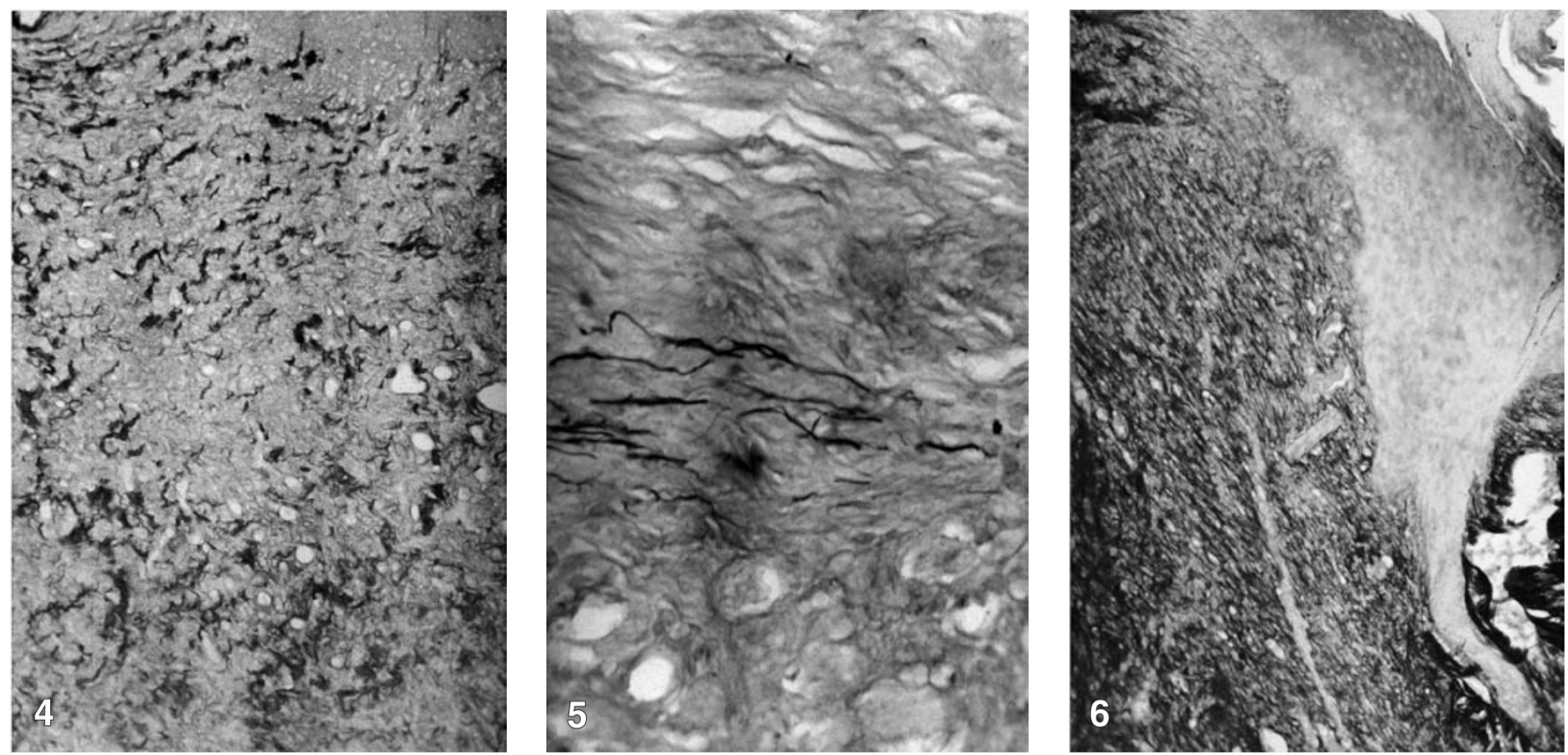

FIGURE 4 - Collagen fibers of a $4 \mathrm{~J} / \mathrm{cm}^{2}$ treated animal; five days (Sirius red,100 X). FIGURE 5 - Distribution of elastic fibers within the wound of a $4 \mathrm{~J} / \mathrm{cm}^{2}$ treated animal; five days (Weigert's orcein, $400 \mathrm{X}$ ). FIGURE 6 - Collagen fibers of a control animal; seven days (Sirius red, $100 \mathrm{X}$ ). 
Pugliese LS, Medrado AP, Reis SRA, Andrade ZA. The influence of low-level laser therapy on biomodulation of collagen and elastic fibers. Pesqui Odontol Bras 2003;17(4):307-13.
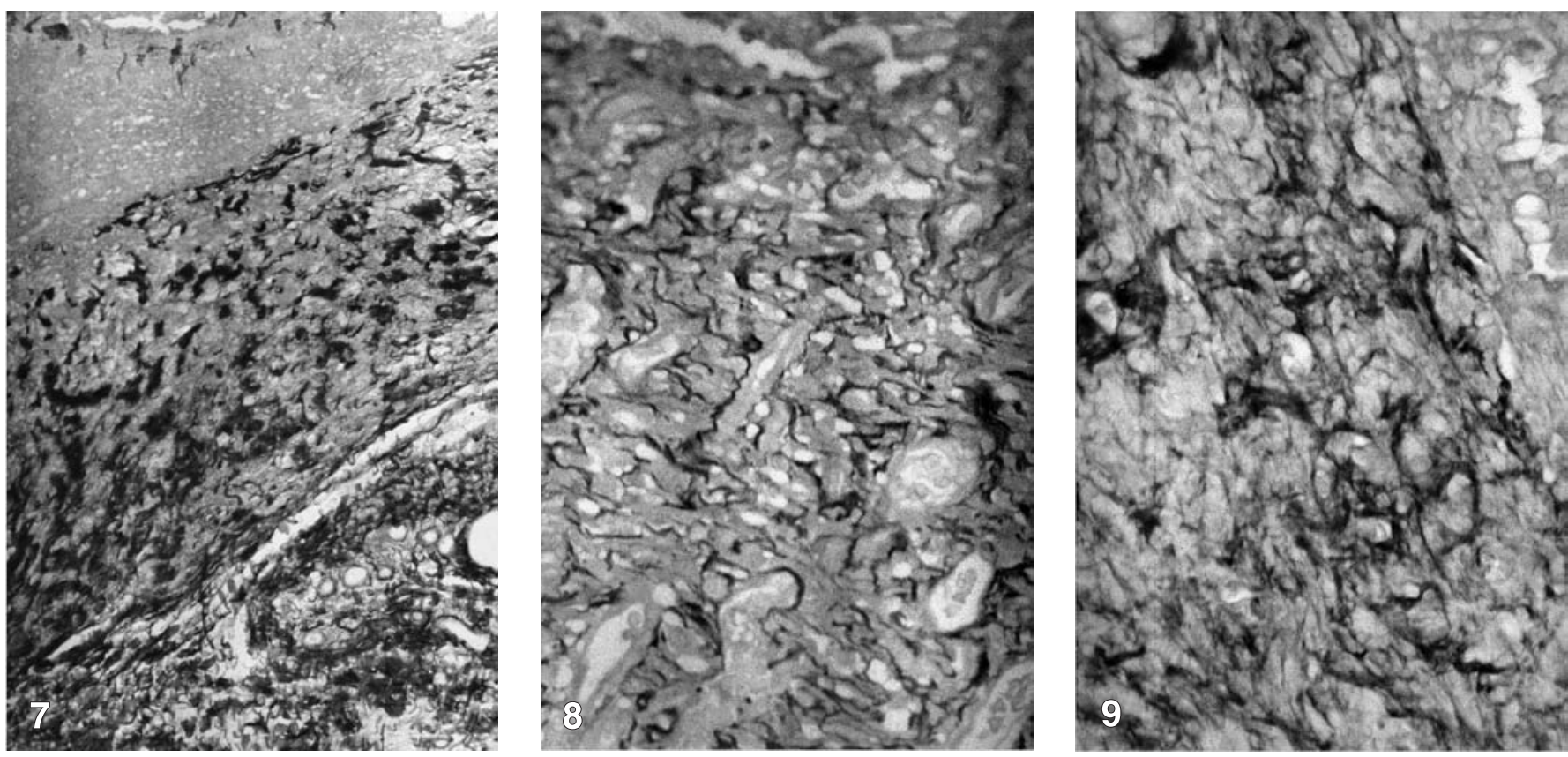

FIGURE 7 - Collagen fibers of a control animal; seven days (Sirius red, $400 \mathrm{X}$ ). FIGURE 8 - Collagen fibers of a $4 \mathrm{~J} / \mathrm{cm}^{2}$ treated animal; seven days (Sirius red, $100 \mathrm{X}$ ). FIGURE 9 - Collagen fibers of a $8 \mathrm{~J} / \mathrm{cm}^{2}$ treated animal; seven days (Sirius red, $400 \mathrm{X}$ ).

ences were registered between the groups. The semi-quantitative analysis demonstrated rising levels of fibers, whilst the healing process evolved, particularly in the groups submitted to the laser light action.

The present investigation sought to characterize the expression of the total collagen present in the cutaneous wound area, through the use of the sirius red stain which reacts specifically with the collagen molecules ${ }^{3}$. During the healing process, it was possible to observe the rising organization of bundles of collagen fibers, while there was a simultaneous increase in the intensity of the coloration of the fibers. In the groups irradiated with laser, the referential graduation was more expressive, especially from the third to the seventh day.

Although there are no data in the literature that indicate a possible biostimulating action of the laser on the elastic fibers, in this study it was observed that the laser contributed to a discreet expression of this fibrilar element in the treated groups, in the more initial phases of the healing process. Since the synthesis of the elastic fibers is a chronologically later event in comparison with that of the collagen fibers, it would be possible to find more accentuated differences between the groups if the period studied was extended from 21 to 30 days.
Various studies were conducted focusing on the analysis of the efficacy of the laser therapy in healing ${ }^{4,6,8}$. However, some pertinent parameters are object of contradictory opinion and the standardization of the methodology used constitutes a true challenge. The diversity of laser types for therapy applied in the development of scientific research represents the first variable to be considered. In addition to this fact, dose and convergence should also be considered. Based on a great quantity of evidence collected over time, Tuner, Hode ${ }^{16}$ approved the use of 1 to $4 \mathrm{~J} / \mathrm{cm}^{2}$ of energy density on the wound, claiming that higher dosages could even exert an inhibiting effect on the healing process.

In the present study, the option was for the use of 4 and $8 \mathrm{~J} / \mathrm{cm}^{2}$, observing that these energy densities allowed a more favorable tissue response regarding the animals of the control group, although no statistical significance was found. Yet, according to some studies that reported the beneficial effects of low energy densities ${ }^{6,8}$, it was noted that the group which received $4 \mathrm{~J} / \mathrm{cm}^{2}$ showed a higher expression of collagen and elastic fibers, at certain sacrifice times, when compared to that of the group that received $8 \mathrm{~J} / \mathrm{cm}^{2}$, even if there were no significant differences. 
Pugliese LS, Medrado AP, Reis SRA, Andrade ZA. The influence of low-level laser therapy on biomodulation of collagen and elastic fibers. Pesqui Odontol Bras 2003;17(4):307-13.

From the observation of these facts, a question arises: through which mechanisms does the laser promote a higher production of collagen during the repair process? In the cutaneous connective tissue, the type I and III collagen are synthesized especially by the fibroblasts activated by growth factors present in the healing micro-environment. In open wounds, myofibroblasts are also present, performing contractile and secretory functions. The increase in the deposit of collagen can occur through a higher proliferation of fibroblastic cells responsible for the synthesis and secretion of this protein, or through an increase in the anabolic cellular activity per se. Therefore, the laser would act through one of these mechanisms, inducing the cellular proliferation or the process of proteic synthesis and secretion, also existing the possibility of both mechanisms occuring simultaneously.

\section{REFERENCES}

1. Alberts B, Bray D, Lewis J, Raff M, Roberts K, Watson JD. Cell junctions, cell adhesion, and the extracellular matrix. In: The biology of the cell. $3^{\text {rd }}$ ed. New York: Garland; 1994. p. 950-1006.

2. Bisht D, Gupta SC, Misra V. Effect of low intensity laser radiation on healing of open skin wounds in rats. Indian $\mathrm{J}$ Med Res 1994;100:43-6.

3. Calvin M. Cutaneous wound repair. Wounds 1998;10:12-32.

4. Gomez-Villamandos RJ, Valenzuela JMS, Calatrava IR. He-Ne laser therapy by fibroendoscopy in the mucosa of the equine upper airway. Lasers Surg Med 1995;16:184-8.

5. Harazaki M, Takamashi H, Ito A. Soft laser irradiation induced pain reduction in orthodontic treatment. Bull Tokyo Dent Coll 1998;39:95-101.

6. Kana SJ, Hutschenreiter G, Haina D. Effect of low-power density laser radiation on healing of open skin wounds in rats. Arch Surg 1981;116:293-6.

7. Loevschall H, Arenholt-Bindeslev D. Effect of low level diode laser irradiation of human oral mucosa fibroblasts in vitro. Lasers Surg Med 1994;14:347-54.

8. Mester E, Spiry T, Szende B. Effect of laser rays on wound healing. Am J Surg 1971;122:532-5.

9. Noble PB, Shields ED, Blecher PDM. Locomotory characteristics of fibroblasts within a three-dimensional collagen lattice: modulation by a Helium/Neon soft laser. Lasers Surg Med 1992;12:669-74.

10. Passarela S, Casamassima E, Molinari S. Increase of proton electrochemical potential and ATP synthesis in rat liver

\section{CONCLUSION}

This study, in particular, sought to contribute to the knowledge of the behaviour of connective fibers under the action of the low-power laser, suggesting that this therapeutic modality can interact in an efficient manner with the various extracellular matrix elements. Based on the analysis of the data obtained, we concluded that the Ga-Al-As laser, operating within the parameters described in this study, induced a biomodulation of the collagen and elastic fibers, evidenced through an increase in the deposit of these fibrilar elements in the animals submitted to laser therapy. The $4 \mathrm{~J} / \mathrm{cm}^{2}$ energy density provided more significant results than the $8 \mathrm{~J} / \mathrm{cm}^{2}$ one.

mitochondria irradiated in vitro by Helium-Neon laser. FEBS Lett 1984;175:95-9.

11. Pinheiro ALB, Cavalcanti ET, Pinheiro ITNR. Low-level laser therapy is an important tool to treat disorders of the maxillofacial region. J Clin Laser Med Surg 1998; 16:223-6.

12. Pourreau-Schneider N, Ahmed A, Soudry M. Helium-Neon laser treatment transforms fibroblasts into myofibroblasts. Am J Pathol 1990;137:171-8.

13. Rochkind S, Rousso M, Nissan M. Systemic effects of low-power laser irradiation on the peripheral and central nervous system, cutaneous wounds, and burns. Lasers Surg Med 1989;9:174-8.

14. Skinner SM, Gage JP, Wilce PA. A preliminary study of the effects of laser radiation on collagen metabolism in cell culture. Aust Dent J 1996;41:188-92.

15. Thomas DW, O'Neill ID, Harding KG. Cutaneous wound healing: a current perspective. J Oral Maxillofac Surg, 1995;53:442-7.

16. Tuner J, Hode L. It's all in the parameters: a clinical analysis of some well-known negative studies on low-level laser therapy. J Clin Laser Med Surg 1998;16:245-8.

17. Tuner J, Hode L. Low level laser therapy - clinical practice and scientific background. Spjutvägen: Prima Books; 1999. 403 p.

18. Yu W, Naim JO, Lanzafame RJ. The effect of laser irradiation on the release of bFGF from 3T3 fibroblasts. Photochem Photobiol 1994;59:167-70.

Recebido para publicação em 15/07/02 Enviado para reformulação em 19/03/03 Aceito para publicação em 09/10/03 